\title{
A multidimensional framework for assessing adaptative justice: a case study of a small island community in the Philippines
}

\author{
Justin See ${ }^{1}$ (D) $\cdot$ Brooke Wilmsen $^{1,2}$ (iD
}

Received: 10 February 2021 / Accepted: 10 November 2021 / Published online: 28 January 2022

(c) The Author(s) 2022

\begin{abstract}
Island communities are the targets for a wide range of interventions designed to help them adapt to climate change. A growing body of research explores the equity and justice implications of adaptation policies and programmes, revealing they often exacerbate, rather than alleviate, inequality within at-risk communities. This paper pushes beyond existing understandings of climate justice, which prioritise its distributive and procedural aspects. Through household surveys, interviews and participant observation, the paper presents a case study of a major adaptation project in a small island community in the Philippines, paying particular attention to its equity implications at the local level. It describes how local politics and power relations distorted the well-intentioned aims of the project and resulted in the project exacerbating, rather than alleviating, pre-existing inequality. Climate change adaptation is a deeply political process that is easily subverted by the interests of the powerful. To mitigate the influence of power and politics in future climate adaptation projects, we present an expanded multidimensional framework for assessing adaptative justice that incorporates the neglected aspects of recognition and structure.
\end{abstract}

Keywords Climate justice $\cdot$ Climate change adaptation $\cdot$ Island community $\cdot$ Fairness $\cdot$ In situ adaptation $\cdot$ Philippines

\section{Introduction}

Extreme weather events are likely to become more frequent in the coming decades with serious implications for many disadvantaged communities in coastal areas and small island nations (IPCC 2014). Recognising these growing risks, national governments, multilateral

Justin See

justin.see@canberra.edu.au

Brooke Wilmsen

b.wilmsen@latrobe.edu

1 Present Address: Centre for Sustainable Communities, University of Canberra, Bruce, Australian Capital Territory 2617, Australia

2 Department of Social Inquiry, La Trobe University, Bundoora, Victoria 3086, Australia 
institutions, and NGOs are investing heavily in a wide range of climate change adaptation projects around the world. For instance, the World Bank (2019) has committed to boost adaptation financing to $\$ 50$ billion from 2021 to 2025 as it plans to support, among other things, 'at least 20 countries... adopt measures to increase their resilience to climaterelated shocks in coastal areas'. While these types of projects are essential to reduce the vulnerability of at-risk communities, there is increasing recognition of their unintended negative effects (Barnett and O'Neill 2010; Eriksen et al. 2011). In their review of 34 adaptation interventions in several developing countries, Eriksen et al. (2021) illustrate how adaptation projects can reinforce, redistribute or introduce new sources of vulnerability. Others warn that adaptation projects are often framed in a top-down manner, leading to inequitable distribution of benefits and the creation of winners and losers (O'Brien and Leichenko 2003; Thomas and Twyman 2005). Some argue these unintended consequences might be avoided if more attention was paid to the concept of justice when designing and implementing adaptation projects (Graham et al. 2015; Paavola and Adger 2006).

In this paper, we expand upon this line of reasoning by arguing the existing literature on just adaptation is overly reliant on the concepts of distributive and procedural justice (see for example, Adger et al. 2016; See and Wilmsen 2020). We argue for greater attention to be paid to pre-existing inequalities in the distribution of wealth, political power and climate risks (Mikulewicz 2018) and the issues of cultural, social and political recognition (Fraser 2009; Schlosberg 2012). To this end, we propose a framework adapted from Pascual et al. (2014) that accounts for the four main dimensions of adaptative justice - distributional, procedural, recognitional and structural (Pascual et al. use contextual) ${ }^{1}-$ and makes explicit the main causal connections between them. We use this adapted framework to analyse a large-scale climate adaptation project carried out by three international NGOs on Tambaliza island in the Philippines.

The paper is divided into five sections. First, we review the existing literature on just adaptation, tracing the intellectual evolution of the concept, before introducing our framework of adaptative justice. Second, we present the case study, describing the study site, the NGOs and communities involved, and the suite of adaptative interventions. Third, we describe our research methods and the indicators used to evaluate our case study through the lens of adaptative justice. We then analyse and explain the successes and failures of these interventions using the adapted framework. In the final section we reflect on the lessons emerging from our case study and framework.

\section{Just adaptation to climate change: A multidimensional framework}

The concept of adaptative justice has its origins in the environmental justice movement of the early 1980s, which began with protests in the United States against the dumping of toxic waste in poor African-American neighbourhoods. Reflecting this history, the early environmental justice literature focused heavily on issues of race and social class (Schlosberg 2004). Over time, the field broadened its horizons; 'a topical expansion has coincided with geographical broadening of the application of the environmental justice frame' (Schlosberg and Collins 2014; see also Edwards et al. 2016). For example, Togias et al. (2010) analyse how low income communities are more likely to be exposed to asthma-inducing pesticides, and Martin et al. (2013) describe how the concept of environmental justice has shaped

${ }^{1}$ We prefer structural to contextual as it delineates the social structure that perpetuates inequity. 
biodiversity conservation. More recently, Mah and Wang (2019) deployed an environmental justice framework to analyse the impacts of oil pollution on workers in Nanjing, China.

The relationship between climate change and environmental justice was first explored in Weiss' (1989) book on intergenerational justice and was expanded in the 1990s, spawning the now ubiquitous term 'climate justice'. The early literature in this area deployed the language of human rights and invoked a diverse set of principles - from historical responsibility to per capita equity to intergenerational equity (Shue 1999) - as it grappled to find an operational definition of climate justice. Researchers have also deployed an environmental justice framework to analyse the mechanisms through which the risks, costs and benefits of climate change are unequally distributed between and within communities (Graham et al. 2015; Paavola and Adger 2006) and how justice can be advanced in the context of these systemic inequities (Barrett 2013; Graham et al. 2018). A subset of the climate justice literature - which we call, adaptative justice - explores the ethical and distributional implications of adaptation policies and projects (Bulkeley et al. 2013; See and Wilmsen 2020; Wilmsen and Rogers 2019).

The existing literature on just adaptation relies heavily on two specific conceptions of justice - distributive and procedural justice. The former is concerned with who enjoys the benefits and who bears the costs of adaptation policies and projects (Dawson et al. 2018). McDermott et al. (2013) argue that theories of distributive justice can be categorised either as consequence-based or rules-based. Proponents of the former (also known as utilitarians) consider social actions to be just if the generated welfare gains outweigh the losses (Mill 1998). Advocates of the latter consider social actions to be just if they result from the application of fair rules. An example of a rules-based approach to distributive justice is prioritanism which gives importance to those who are relatively worse off in society (Adler 2012). Sikor et al. (2014) warn that it is difficult to justify the utilitarian principle of the aggregate good in a setting such as the Global South where there is pronounced economic inequality. Adams et al. (2004) also cited instances where environmental governance guided by utilitarianism displaced vulnerable people and excluded them from key sources of livelihood. Our understanding of distributive justice thus follows prioritanism, which means that those with the greatest needs should be given the greatest benefits from adaptation programmes.

Procedural justice refers to the fairness of institutional processes through which policy and project decisions are made (Young 1990). It is concerned with questions of due process - such as whose voices are heard and whose interests prevail in decision-making fora (Martin et al. 2014, 2015). According to Adger et al. (2006), 'participation of most impacted and vulnerable groups is vital for adaptation planning in all developing countries'. Scholars have recently expanded the conceptualisation of procedural justice to include other norms such as accuracy, transparency, correctability and reciprocity (Brandstedt and Brülde 2019). Others also stress the importance of addressing procedural justice in climate adaptation. Holland (2017), for instance, states that theories of procedural justice help 'conceptualise, deconstruct, and propose solutions to structural inequalities that make some people the subjects of institutionalised forms of domination'.

While distributive and procedural justice both possess a unique emphasis and objective, scholars argue that these should be addressed simultaneously in a broader and inclusive understanding of climate justice (Bulkeley et al. 2014; Schlosberg 2007). There is a clear link between the two: distributive justice is unlikely to be achieved without procedural justice. However, recent scholars highlight the need for a multidimensional conceptualisation of justice and contend that other factors, such as recognition and social structure, should also be taken seriously (Pascual et al. 2014). Recognitional justice refers to the extent in 
which groups are granted status, legitimacy and respect so they can take part and adequately represent their interests and positions (Popke et al. 2016). According to Honneth (1995), failure to recognise the existence and rights of particular social groups constrains opportunities and inflicts harm upon them through degradation and devaluation, and therefore constitutes a form of injustice in its own right. The remedy for such injustice is 'recognition for the previously discriminated against, derided, or ignored to gain participatory parity' ((Schlosberg 2012), p. 452). The principle of participatory parity demands all people be able to engage in social life as peers (Fraser 2010) and requires significant investments of time, energy and resources into making sure all voices are recognised, included and incorporated into policy and project decisions.

The literature also identifies a fourth dimension of justice - structural context - that underpins the three dimensions mentioned above. We draw upon Young's (2011) interpretation of structural injustice as 'structural processes (that) put large groups of persons under systematic threat of domination or deprivation... at the same time that these processes enable others to dominate or to have a wide range of opportunities... available to them'. This type of injustice is not traceable to specific individual actions, but is the result of large scale processes comprising the confluence between social norms, institutional rules, as well as individual and collective actions (Beck 2020). In this paper, we not only look at the uneven playing field brought about by pre-existing asymmetries in wealth and power (McDermott et al. 2013), we also explore social arrangements and structures that may be deeply implicated in the production and persistence of inequities in the first place.

The distinction between the four different forms of justice - distributive, procedural, recognitional and structural - is for analytical purposes. In practice, the four facets of justice are mutually reinforcing: without recognition or a strong understanding of pre-existing contexts, procedural justice is impossible to achieve, and distribution is likely to be inequitable. For example, if politicians, bureaucrats and project proponents fail to recognise the existence and needs of vulnerable groups - or these groups lack the resources to ensure their voices are heard - they have little hope of participating meaningfully in decision making processes and, thereby, achieving procedural justice and distributive justice (Franks and Schreckenberg 2015). These relationships are captured in Pascual et al.'s (2014) 'Four Dimensions of Social Equity' Framework which extends McDermott et al.'s (2013) three dimensional equity framework (distributional, procedural and contextual) to include recognitional equity. Both scholars developed and applied their frameworks to the field of ecological conservation to expand what they saw as a one-dimensional focus on equity in the delivery of ecosystem services. In this study we adapt this framework to expand what we observe as a two-dimensional view of adaptative justice in the climate change literature (see Fig. 1).

Our framework makes a few important amendments to Pascual et al. (2014). We use a pyramid structure to recognise the hierarchical relationship between structural, recognitional, procedural and distributive conceptions of justice. We draw attention to how these different conceptions of justice focus the analytical gaze on different parts of the process by which policymakers and project proponents define problems and identify targets (context), engage and negotiate with stakeholders (process), and implement and assess their adaptative interventions (outcomes). We place structural and recognitional justice at the bottom of the pyramid to emphasise that procedural and distributive injustices often result from an earlier failure to recognise the rights - and indeed, existence - of particularly vulnerable groups and pre-existing inequalities in the distribution of economic resources, political power and climate risks. Recognitional injustice - defined by Fraser (1997) as domination, nonrecognition and disrespect - might be considered a sub-category of (pre-existing) 


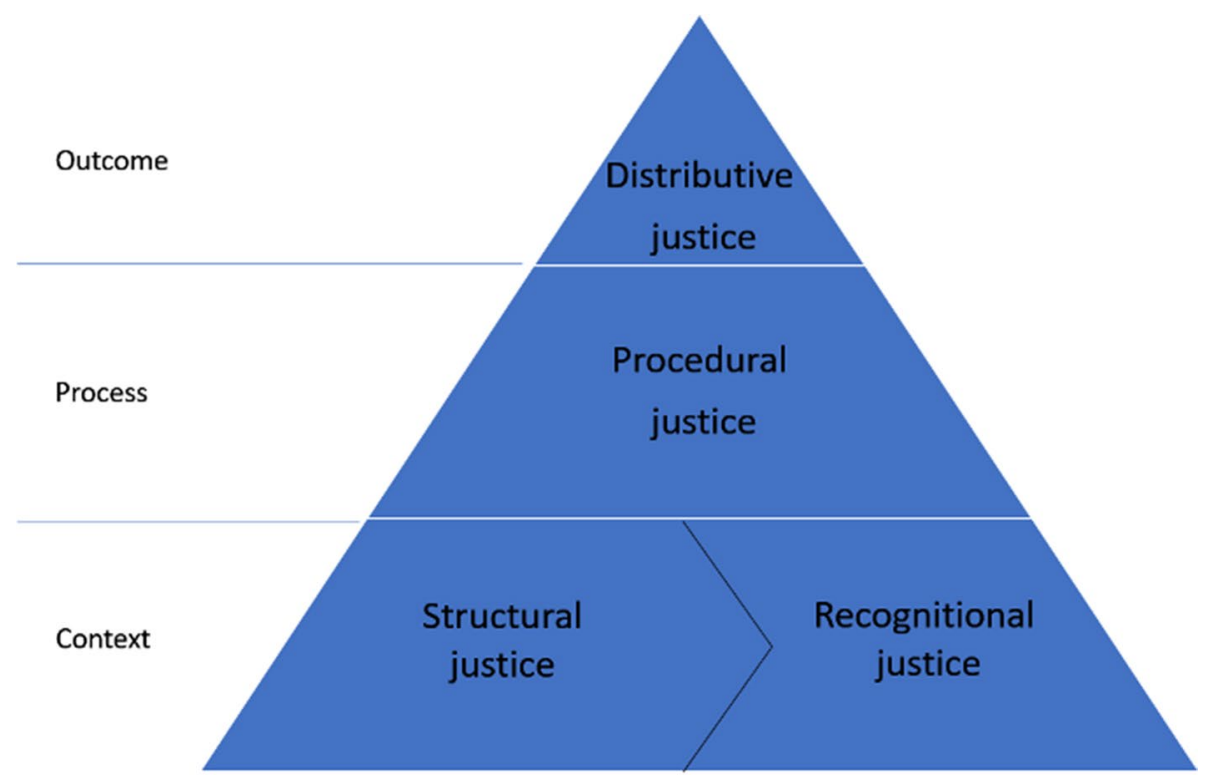

Fig. 1 Adaptative justice analytic framework. Source: Authors

structural injustice. However, we give recognitional justice independent status in our framework because questions of culture, identity and respect are too often neglected by policymakers and project proponents. In the longer term, distributive (in)justice feeds back into recognitional and structural (in)justice, but for simplicity's sake this is not marked in Fig. 1.

\section{Case study background}

The focus of our case study was a series of adaptation projects carried out on Tambaliza island in the northeast of Iloilo province in the Philippines. The island has a land area of approximately 775 square hectares and a population of 3403, comprising 719 households (Philippine Statistics Authority 2017). Its primary source of income is fishing, followed by farming. Several households also raise poultry and livestock for local consumption. The barangay $^{2}$ of Tambaliza is divided into seven sitios. Six of these sitios (Proper, Banban, Bat-os, Guinmisahan, Pasil and Punting) are coterminous, with the remaining sitio (Bot$\log$ ) geographically isolated from the rest (Fig. 2).

Tambaliza is susceptible to four climate-related hazards: storm surges, sea level rise, typhoons and droughts (Bgy Tambaliza 2012). While all sitios are susceptible to sea level rise, typhoon and drought, Botlog, Bat-os and Punting are exposed to the Visayan Sea and are particularly vulnerable to storm surges. Abian (2016) estimates that $40 \%$ of households that reside within $40 \mathrm{~m}$ of the sea on Tambaliza will be completely

${ }^{2}$ A barangay is the smallest administrative unit in the Philippines. 


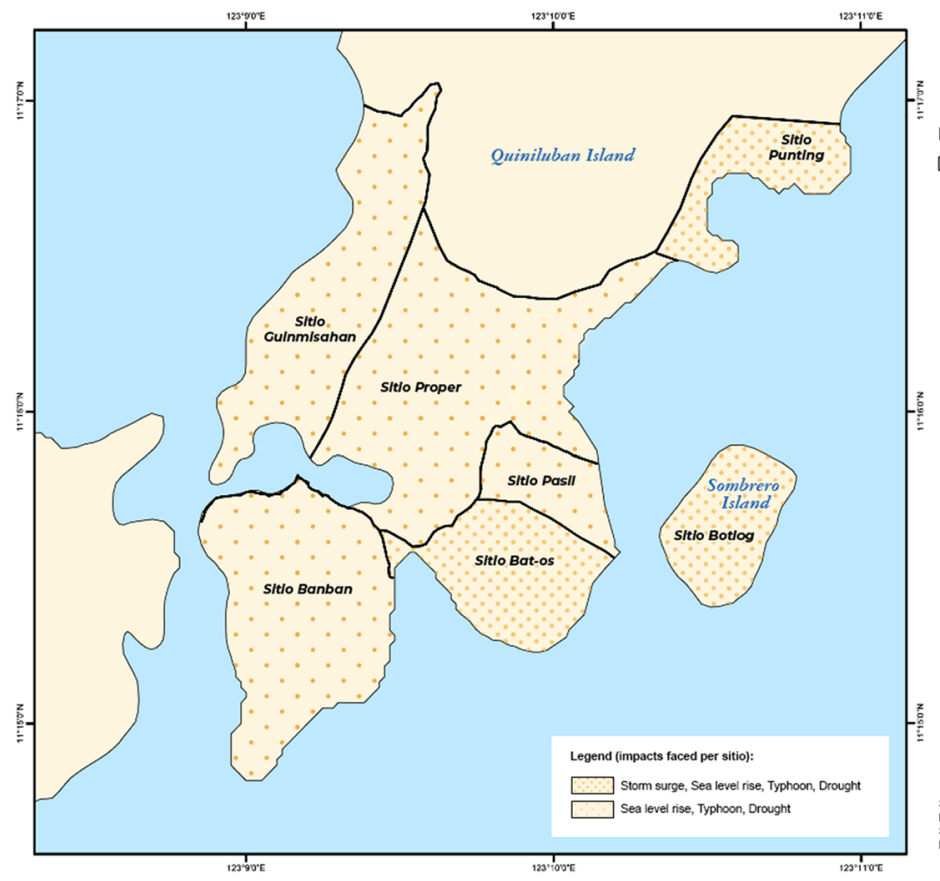

Barangay Tambaliza

Concepcion, lloilo

Legend

$\square$ Sitio Boundary (Approximated)
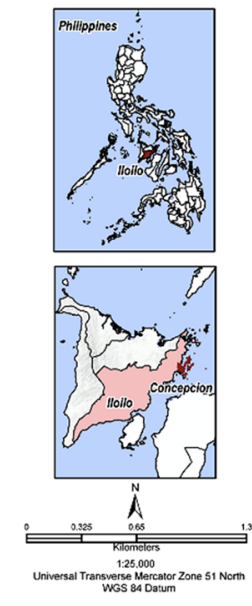

Souroe: Strio Boundary from Resource Map of

Fig. 2 The island of Tambaliza in Concepcion, Iloilo. Source: Authors

inundated by 2035. The Municipal Disaster Risk Reduction and Management Plan of Concepcion (2017, p. 20) states that the entire municipality (including Tambaliza) has 'typhoon and drought severity ratings of $100 \%$ based on the probability of occurrence and percentage of impact'. Typhoons usually result in metre high floods, which cause significant damage to rice fields. During the summer, sources of water on Tambaliza often dry up, 'affecting vegetation, livestock and people... (who) fear the burdensome process of fetching water from other areas' ((Municipality of Concepcion 2017), p. 25).

Tambaliza is located in the municipality of Concepcion, one of the most disadvantaged municipalities in Iloilo, with a poverty incidence of $57.1 \%$ (National Statistical Coordinating Board 2009). Living conditions on the island are severely impacted by extreme weather events. In November 2013, Typhoon Haiyan destroyed 2662 boats, amounting to 900,000 USD ((Municipality of Concepcion 2017), p. 17) and damaged 2956.42 ha of agricultural land worth 1.7 million USD ((Municipality of Concepcion 2017), p. 16). Infrastructure such as electricity, roads and government buildings were also damaged (Lum and Margesson 2014). While all the sitios on Tambaliza were drastically affected, none was more severely devastated than Botlog, where all 51 houses were destroyed (Penaflor 2013).

Typhoon Haiyan was an important turning point, drawing attention to the high costs imposed on Tambaliza by climate change and instigating a range of interventions by domestic and international agencies. These interventions occurred in three stages. Between 2013 and 2014 an emergency relief phase involved the provision of emergency food and shelter kits. In 2015, programmes focused on improving food security and livelihoods. Then, in 2016 development agencies rolled out a range of climate adaptation projects to lower the risks associated with extreme weather events (Hanley et al. 2016). This research 
focuses on the procedures and outcomes of three adaptation projects carried out in this final phase of the post-Typhoon Haiyan recovery programme.

\section{Research methods}

Data were collected from April to July of 2018 by a research team composed of graduate students from a public university in Iloilo City, Philippines. Household surveys, semistructured interviews and participant observation were used to collect data about the four dimensions of adaptative justice - distributive, procedural, recognitional and structural (see Online Resource 2). All data were collected in the local language, Hiligaynon, and later translated to English.

Questionnaires were distributed to 100 households using a stratified sampling technique to ensure that all sitios were represented. This required the population of respondents to be divided into sitios with a random sample drawn from each. Every fifth household in every sitio was approached by the team and invited to participate (see Online Resource 1). To further explore the respondents' perceptions of fairness of the adaptation programmes, semi-structured interviews were conducted with community members, leaders and NGO staff. Sampling for the interviews was purposive: interviewees were selected based on their experience with the planning, implementation and participation in the adaptation projects. A total of 20 interviews were conducted.

Participant observation was employed to better understand the dynamics of the public forums and community consultations. Two participatory workshops were organised to build familiarity between residents and the researcher and to understand their experiences with the climate adaptation projects. The meetings were facilitated by NGO staff members and were attended by the local residents. At the meetings, the first author noted who attended, the frequency of issues raised, the number of times each attendee spoke and the flows of conversation. Each meeting lasted for approximately two hours and, with the participants consent, were recorded using an audio recorder.

The survey data were encoded, cleaned and analysed using SPSS. The respondents' socio-demographic characteristics and perceptions of adaptative justice were then extracted for analysis. We used Pearson chi-square test to compare perceptions of the different types of adaptative justice across the sitios. $P$ values that are less than 0.05 are considered statistically significant. To identify which variables contributed to the statistically significant effect, we employed standardised residual analysis (Sharpe 2015). Following Agresti (2007), standardised residuals greater than +2.0 and -2.0 reflect significantly 'greater discrepancy than we would expect if the variables were truly independent'. Meanwhile, we used NVivo 11 to code the qualitative data and arrange themes from the interviews into nodes and those with the highest prevalence were illustrated with participant quotes and photographs. Finally, the observational data from the workshops were encoded in Excel and exported to SPSS to generate descriptive statistics of the issues faced by the community.

Just like any other survey that relies on self-assessments, the validity of our findings may suffer from the participants' tendency to respond in ways that will be perceived favourably by the interviewers. We addressed this by ensuring anonymity, choosing neutral wording and avoiding questions that suggest a socially desirable response. While social desirability bias cannot be excluded, Krumpal (2013) argues that it is more often associated with anti-social attitudes and illegal behaviours. Another limitation is the study's 
small sample size and its specificity to a coastal community which can limit the generalisability of our findings to other contexts. However, this study is intentionally localised and we employed multiple methods to establish corroboration and data triangulation. Finally, the lack of available meteorological data and hazard maps on a sitio scale in Tambaliza is another limitation. Consequently, the intensity and spatial extent of typhoons were therefore not taken into consideration in our analysis.

This research analyses adaptation projects implemented by three international NGOs active in the study area. To ensure anonymity, we refer to these NGOs as Sacred Aid UK, British4Environment and First Response Ireland. Sacred Aid UK is a religious development agency in the UK that provides disaster relief to developing countries, British4Environment is a British charity organisation that promotes the conservation of the environment and finally, First Response Ireland is an Irish aid organisation that provides emergency relief and health services. They were chosen for three reasons. First, their project slogans and logos were ubiquitous in the barangay and they were frequently mentioned by the residents during exploratory fieldwork. Second, the first author has existing connections with the NGOs from previous projects and they expressed willingness to be observed and interviewed. Finally, they carried out a range of climate adaptation projects across Tambaliza.

\section{Results}

In this section, we describe and analyse the outcomes of the adaptation projects carried out by the NGOs using our framework of adaptative justice (Fig. 1). We begin by exploring how the NGOs engaged with local politicians and community members in the selection, design and rollout of their adaptation programmes (procedural justice). We then analyse how the benefits of these interventions were distributed across the sitios and within the communities (distributive justice). In the section that follows, we examine the pre-existing socio-cultural conditions (structural justice) and how these influence who is recognised in the implementation of adaptation programmes (recognitional justice).

\subsection{Procedural justice}

Procedural justice requires that affected communities can meaningfully influence decisionmaking processes (Paavola 2006, 2008). To explore procedural justice, our interviews and household survey asked whether residents were meaningfully involved in the planning and implementation of the adaptation projects and to what extent they were able to shape decisions.

Table 1A reveals large differences across the sitios in terms of perceptions of procedural justice. For example, in Proper and Banban, $80 \%$ or more of respondents agreed that the NGOs asked for their opinion when planning adaptation projects, listened to them and considered their views, and involved them in the programmes. In contrast, in Botlog and Punting the level of agreement with these statements ranged between $30 \%$ and $40 \%$. The responses of residents of Proper, Botlog and Punting drove the significant differences in perceptions of procedural justice.

To further explore procedural justice, the NGOs invited us to attend two participatory workshops intended to seek community feedback about the adaptation projects. These meetings, held at the community hall in Proper, provided an opportunity to observe, firsthand, the NGOs' community engagement strategies. Most of the workshop 


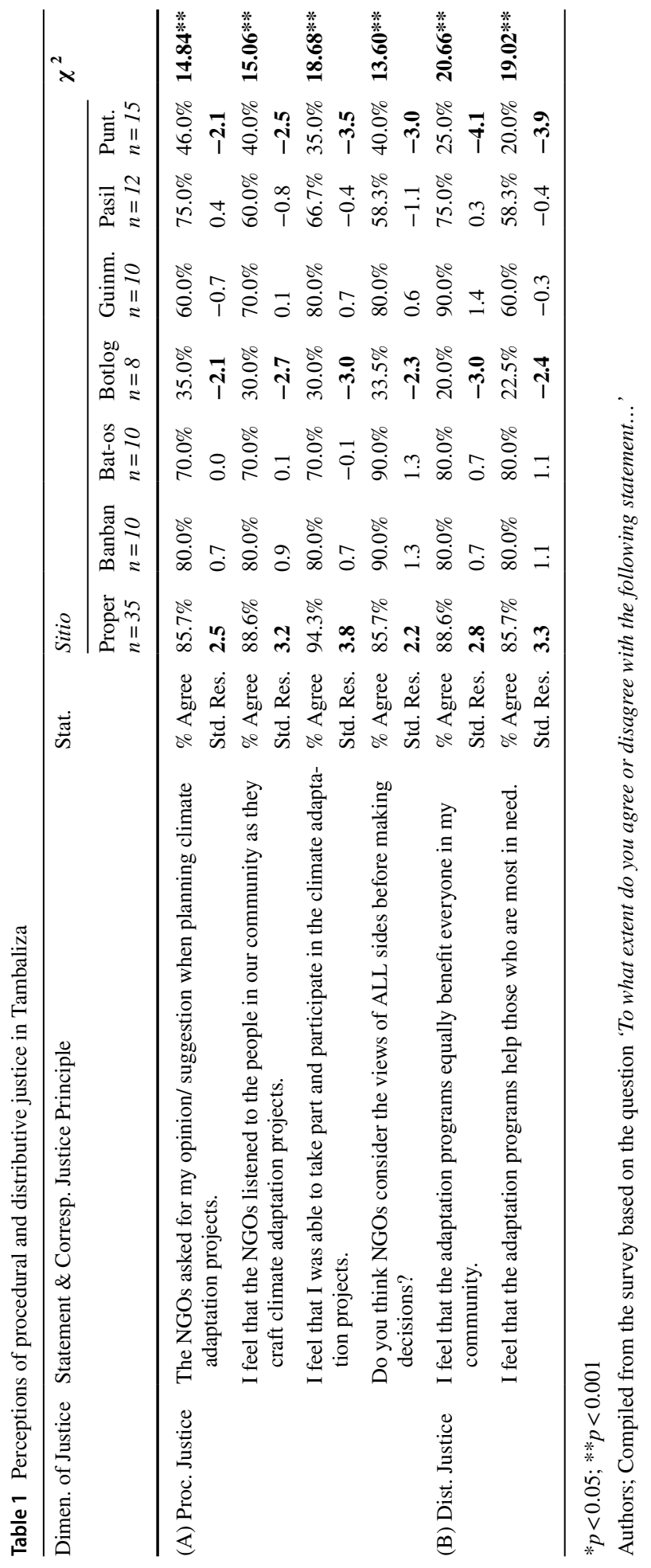




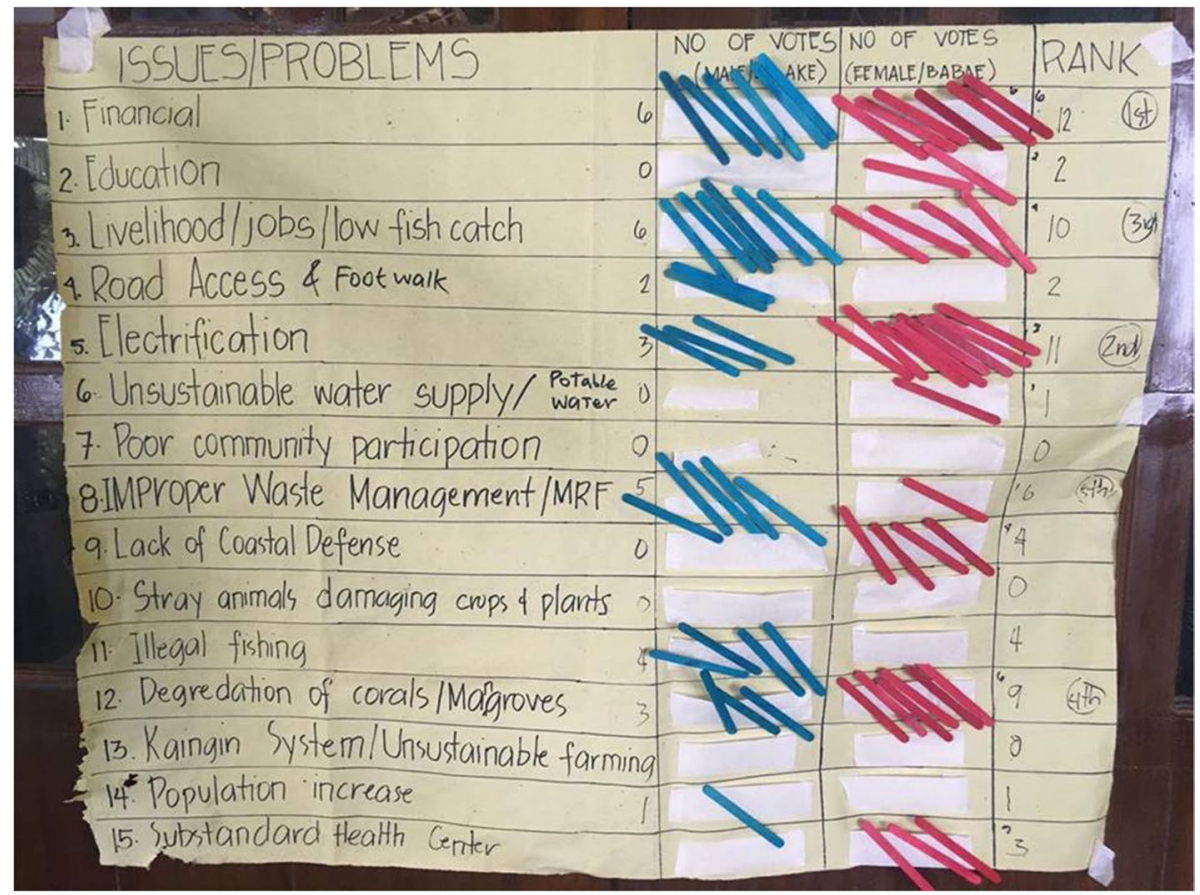

Fig. 3 Issues identified by the residents during the community consultation. Source: Authors

participants came from Proper $(n=6)$, Banban $(n=4)$ and Guinmisahan $(n=3)$. No residents from Botlog were able to attend, and only one person from Punting was able to attend. Workshop participants were asked to identify the most pressing issues facing their community. Figure 3 provides an example of the type of feedback this generated. Participants were asked to list the issues facing their communities and to select the three most important issues to produce a ranked list. The top five issues identified were: (1) financial (lack of income) $(n=12)$; (2) electricity (inadequate supply) $(n=11)$; (3) livelihood (dearth of employment aside from fishing) $(n=10)$; (4) degradation of coral and mangroves $(n=9)$, and (5) waste management $(n=6)$. While the three most important issues identified through this process were consistent across all sitios, the major problems identified by the residents of Botlog and Punting during the interviews - lack of potable water $(n=1)$, concrete footpaths $(n=2)$ and substandard health services $(n=3)$ - were given little attention in the workshops because only a few representatives attended. Furthermore, no effort was made to conduct the workshops or meetings elsewhere so people from these sitios could participate in greater numbers.

We raised concerns about the under-representation of residents from some sitios with an NGO official. She stated, 'it is not uncommon to have few representatives from the two sitios because they are really far and our funding for meetings is limited' (personal communication, Sacred Aid UK, June 16, 2018). This skewed attendance at the workshop helps explain the differences in perceptions of procedural justice and the need for adequate resources to address practical impediments to participation, such as travel time and costs. 
Table 2 Access to infrastructure services

\begin{tabular}{llllll}
\hline \multirow{2}{*}{ Sitio } & \multicolumn{5}{l}{$\%$ of respondents reporting inadequate access } \\
\cline { 3 - 6 } & $\mathrm{N}$ & Access to electricity & Access to water & $\begin{array}{l}\text { Access to health } \\
\text { services }\end{array}$ & Access to education \\
\hline Proper & 35 & 43 & 9 & 26 & 0 \\
Banban & 10 & 50 & 0 & 10 & 0 \\
Bat-os & 10 & 50 & 0 & 50 & 0 \\
Botlog & 8 & 75 & 63 & 75 & 63 \\
Guinmisahan & 10 & 50 & 0 & 20 & 0 \\
Pasil & 12 & 42 & 7 & 17 & 60 \\
Punting & 15 & 66 & 17 & 47 & 60 \\
\hline
\end{tabular}

Authors; Compiled from the survey based on the question 'how would you rate the quality of the following infrastructure in your sitio?'

Our interviews also revealed the important role played by barangay officials in shaping local residents' participation. One respondent shared 'our barangay takes an active role in drafting beneficiary lists and distributing goods and resources on behalf of the NGOs' (Female, Banban, June 10, 2018). All three NGOs proactively engaged with the barangay, mindful that trying to bypass local officials can seriously impede the roll-out and effectiveness of their projects. This is similar to other studies that found that engaging with powerful local groups and individuals is a common strategy amongst NGOs to ensure the success of projects and, thereby, secure more funding in the future (Roche 2000; Vähämäki 2015).

The close relationship between the NGOs and the barangay was criticised by interviewees on two accounts. First, some barangay officials directed the NGOs to focus activities within their own constituencies. Because positions in the barangay are subject to change with each election, barangay officials are under pressure to showcase their ability to secure projects and funding for their constituents. One resident remarked: 'When new livelihood programmes are implemented in our locale, we somehow feel indebted to our local leaders for making it happen. We don't hesitate when it's their turn to ask for help from us' (Male, Proper, June 12, 2018).

In some instances, this resulted in outright nepotism. Interviewees stated that barangay officials tended to prioritise their own family and friends when negotiating with the NGOs about the location of projects. In fact, all three of the barangay officials we interviewed talked about the importance of helping one's family first before anyone else. One official admitted: 'It is probably human nature. When you see that your own relative is in need, you will really help him or her out. Blood is thicker than water... I think it is better to help your family first.' (Female, Banban, June 10, 2018). Another official admitted that she owes a lot of things to her family: 'I would not be where I am now without their help throughout the years. I don't think I can say no to helping them' (Male, Proper, June 12, 2018).

\subsection{Distributive justice}

Distributive justice is concerned with how the benefits and costs of adaptative interventions are distributed (Franks and Schreckenberg 2015) and whether scarce resources are channelled to those subject to the greatest climate risks. The skewed participation of people from the different sitios in the community engagement processes presented in the previous section, combined with the power of local officials, impacted the distribution of resources. 
Table 3 Residence of the Barangay Officials and Implementation of Adaptation Programmers

\begin{tabular}{|c|c|c|c|c|c|c|c|}
\hline & Proper & Banban & Guinmisahan & Pasil & Bat-os & Botlog & Punting \\
\hline Population & 1010 & 404 & 322 & 252 & 357 & 273 & 785 \\
\hline Total No. of Local Officials & 4 & 3 & 2 & 0 & 1 & 0 & 0 \\
\hline Total Adaptation Interventions Reported & 10 & 10 & 9 & 6 & 8 & 4 & 3 \\
\hline Training, workshops & $\checkmark$ & $\checkmark$ & $\checkmark$ & $\checkmark$ & $\checkmark$ & $\checkmark$ & $\checkmark$ \\
\hline Early Warning & $\checkmark$ & $\checkmark$ & $\checkmark$ & $\checkmark$ & $\checkmark$ & $\checkmark$ & $\checkmark$ \\
\hline Community savings scheme & $\checkmark$ & $\checkmark$ & $\checkmark$ & $\checkmark$ & $\checkmark$ & $\checkmark$ & $\checkmark$ \\
\hline Infrastructure 1: Water & $\checkmark$ & $\checkmark$ & $\checkmark$ & $\checkmark$ & $\checkmark$ & $x$ & $x$ \\
\hline Infrastructure 2: Footpaths & $\checkmark$ & $\checkmark$ & $\checkmark$ & $x$ & $\checkmark$ & $x$ & $x$ \\
\hline Housing & $\checkmark$ & $\checkmark$ & $\checkmark$ & $\checkmark$ & $\checkmark$ & $x$ & $x$ \\
\hline Marine protection & $\checkmark$ & $\checkmark$ & $x$ & $\checkmark$ & $\checkmark$ & $\checkmark$ & $x$ \\
\hline Mangrove rehabilitation & $x$ & $\checkmark$ & $x$ & $x$ & $\checkmark$ & $x$ & $x$ \\
\hline Aquaculture & $x$ & $\checkmark$ & $\checkmark$ & $x$ & $x$ & $x$ & $x$ \\
\hline Livelihood 1: Cassava processing & $\checkmark$ & $x$ & $x$ & $x$ & $x$ & $x$ & $x$ \\
\hline Livelihood 2: Gardening & $\checkmark$ & $\checkmark$ & $\checkmark$ & $x$ & $x$ & $x$ & $x$ \\
\hline Livelihood 3: Animal raising & $\checkmark$ & $x$ & $\checkmark$ & $x$ & $x$ & $x$ & $x$ \\
\hline
\end{tabular}

represents the presence of adaptation interventions while $\boldsymbol{X}$ represents the absence Authors' calculations using data provided by the barangay

Table 2 suggests that the respondents from Botlog and Punting do not have adequate access to electricity, potable water, health and education services. The principle of distributive justice, therefore, would suggest the NGOs should have prioritised these two sitios when deciding how to allocate their resources.

In reality, Botlog and Punting were not prioritised. Interviewees in the more prosperous sitios were more likely to report an NGO intervention in their area than interviewees in the less prosperous sitios. For example, across the 13 categories of adaptative interventions, ten were reported in Proper and Banban, whereas in Botlog and Punting, only four and three were reported, respectively. Moreover, Table 3 demonstrates that, apart from Bat-os, adaptation interventions were concentrated in sitios where barangay officials and their constituencies reside - Proper, Banban and Guinmisahan.

The types of interventions also differed between the sitios. Table 3 illustrates that the more prosperous sitios of Proper, Banban and Guinmisahan received a range of reactive and proactive interventions, ${ }^{3}$ whereas the less prosperous sitios of Botlog and Punting received mainly reactive interventions, such as preparedness training and early warning devices, which did little to improve livelihood resilience. Furthermore, infrastructure such as water and concrete footpaths, were not constructed in Botlog or Punting despite being

\footnotetext{
${ }^{3}$ Following the typology of adaptation actions proposed by Smit et al. (2000), the NGOs' adaptation interventions can be broadly classified according to their temporal scope: (1) reactive referring to measures that alleviate the impacts of climate change in the short term or (2) proactive pertaining to actions taken even before the impacts are experienced. The reactive measures implemented by the NGOs in Tambaliza included disaster trainings and early warning systems, while the proactive measures consisted of infrastructure development, livelihood diversification, marine protection, mangrove restoration and community savings schemes.
} 
constructed in other sitios. In short, the distribution of adaptative interventions reproduced, if not exacerbated, pre-existing inequalities between the sitios.

Unsurprisingly, the unjust allocation of resources influences perceptions of distributive injustice. The survey asked respondents about whether they felt the adaptation projects were fairly distributed. Table $1 \mathrm{~B}$ demonstrates that respondents from the less prosperous sitios were far less likely to agree that the interventions were fairly distributed within and between communities than respondents from the more prosperous sitios. For example, in Botlog and Punting only $22.5 \%$ and $20 \%$ of respondents, respectively, agreed that the adaptation projects helped those who are most in need, compared to $85.7 \%$ in Proper.

We now turn to issues of structural and recognitional justice to examine the social, cultural and institutional conditions that underpinned the inequitable procedures and distributions described above.

\subsection{Structural justice}

We understand structural injustice as the large-scale processes comprising social norms, institutional rules, as well as individual and collective actions that put groups of people under systematic threat of deprivation (Young 2011). Whilst a multitude of norms, rules and actions could have been observed, two factors stood out from our empirical data: (1) patron-client relationships and (2) cultural norms of saving face and reciprocity. The former reinforces the pre-existing inequitable social conditions in Tambaliza, while the latter helps explain the unequal recognition accorded to each of the sitios by the NGOs (section 5.4).

Following McDermott et al. (2013), we explored 'what kind of inequity is present at the starting point.' A review of the socio-economic data provided by the barangay highlighted important differences in living standards across the sitios before the adaptation programmes were implemented. The residents of Proper were the most educated and the most diverse livelihoods (see Online Resource 3). In contrast, Botlog and Punting had the largest number of disabled and senior citizens - two groups that struggle to recover their livelihoods in the wake of natural disasters (Peacock et al. 1997; Tapsell et al. 2002).

The disparities were acknowledged by the NGOs which claimed that their adaptation programmes were attuned to the needs of the most vulnerable. For instance, in its project reports, First Response Ireland claimed that it coordinated with the 'local government unit and barangay officials ... (to) identify those who were more vulnerable such as the elderly and the disabled so they could be targeted for assistance first...' ((First Response Ireland 2016), p. 8). Similarly, Sacred Aid UK stated that 'their projects have needs assessments and targeting criteria which are effective in targeting the most vulnerable and worse affected' ((Sacred Aid 2016) p. 6). British4Environment also emphasised that its activities took 'into account the needs of women, indigenous and local communities, and the poor and the vulnerable' ((British4Environment 2017), p. 77). In short, all three NGOs claimed that they paid sufficient attention to pre-existing inequalities.

Despite the rhetoric, the NGOs failed to acknowledge the complex societal arrangements and structures that saddled Tambaliza with a legacy of injustices such as poverty and lack of economic opportunities. These preceded the climate adaptation interventions introduced by the NGOs on Tambaliza and continued to undermine their interventions with implications for the multiple dimensions of justice. For instance, the Philippines embarked on a major decentralisation program in the 1990s which saw the majority of investments concentrated in urban centres (Hill 2008). As such, patron-client relationships became an 
important means through which those outside of cities could access welfare. Patron-client relationships are defined as an instrumental friendship between two individuals of different status in which the patron... provides for the protection and material welfare of his lower status client... who reciprocates by offering general support and assistance' ((Scott and Kerkvliet 1977), p. 440). In Tambaliza, patrons are commonly the local officials who provide goods and services while the clients are their constituents who receive financial capital in exchange for loyalty, voter support and other favours. Our interviews suggest that patron-client relations contributed to the inequalities in the socio-economic data in Tambaliza observed before the NGOs began their climate interventions. For instance, half of the interviewees complained that relief interventions immediately after Typhoon Haiyan were not distributed evenly. One respondent explained the nature of the problem: 'There was a lot of hocus-pocus with the distribution of help. I was surprised to see that my neighbour suddenly received two fishing boats while I got none!' (Male, Botlog, June 14, 2018). Another respondent commented that those who were 'lapit sa luwag' (close to the ladle), i.e. residents who were well-connected to local government, received their boat donation faster than those without connections. Patron-client relationships thus helped the residents with political links to government get back on their feet faster than those who did not.

Accumulated actions and practices of people adhering to social and cultural norms can also bring about unintended structural consequences (Young 2011). While not exclusive to Filipinos, two virtues that were frequently brought up during the interviews were hiya (to save face) and utang na loob (reciprocity). According to Enriquez (1993), Filipinos place high value on self-image and are afraid to lose face. One of the three NGO officials we interviewed stressed the importance of reputation: 'we feel pressured to demonstrate tangible results to our funders. It is not explicitly talked about, but we feel bad if we do not meet their expectations' (Female, First Response Ireland, June 27, 2018). The need to save face and showcase 'results' has translated to selective project implementation where sitios with better socio-economic conditions are favoured over poorer sitios in greater need. This reflects the practice of 'betting on the strong' which has shown to amplify existing inequalities (Rogers 2014). Utang na loob or the practice of returning favours was also mentioned in the interviews. The majority of respondents alluded to having returned the generosity of local politicians (10 of 20) and their own family members (18 of 20). Three NGO officials interviewed also talked about the importance of reciprocity. Interviewees value utang na $l o o b$ as those without it are considered shameless --- an expression Filipinos resent (Mercado 1976). The cultural norms of hiya and utang na loob, in turn, helped determine who was recognised as deserving of the NGOs' adaptation programmes.

\subsection{Recognitional justice}

The recognition of the rights and vulnerabilities of people is a pre-requisite for achieving procedural and distributive justice (Schlosberg 2007). Two themes pertaining to recognitional justice emerged from our field interviews: (1) membership in People's Organisations (POs) and (2) attendance in previous NGO projects. Both themes contribute to the structural injustice in Tambaliza as those recognised as deserving of involvement in the adaptation programmes were mostly existing members of well-established POs or were active in the NGOs' other projects.

Interviewees emphasised the importance of being part of a PO to engage with the NGOs. POs are grassroots, membership-based collectives defined in the Philippine Constitution (Article XIII, Section 15) as having 'capacity to promote public interests and with 
identifiable leadership, membership and structure' (Republic of the Philippines 1987). All interviewees who were members of a PO were provided with alternative livelihoods as part of the NGOs' adaptation programmes. An official from a PO called the Tambaliza Fisherfolks Association explained that most of the NGOs only engage with POs and not individuals. He stressed that 'residents who do not belong to an organised group are not included in the adaptation projects' (Male, Guinmisahan, June 20, 2018). Another resident explained why the NGOs were overly eager to work with POs: 'we make things easier for them. They don't have to organise from scratch. Plus, we have a very good track record of making sure that their projects work' (Male, Banban, June 22, 2018). Although PO membership is free, members are required to attend monthly meetings. Many struggle to attend these meeting due to work and family responsibilities. One respondent shared: 'given the chance I would have loved to join all those meetings. But I must tend to my family first and make sure that I can feed them' (Male, Botlog, June 14, 2018). There were several coding references $(\mathrm{f}=7)$ from our qualitative analysis attributed to difficulties in attending PO meetings, two of which cited that they were dismissed from their own POs because they were unable to regularly attend meetings.

Another precondition for achieving recognitional justice is participation in previous NGO projects. The majority of interviewees mentioned that residents who regularly attended NGO activities were prioritised in their adaptation programmes. A respondent from Banban shared that 'there are dual citizens (those lucky to be selected for two or more projects) and celebrities (those who are always present in projects) in our community' (Female, June 12, 2018). All NGO officials interviewed revealed that they tracked attendance to see who frequently participated in disaster simulations, first aid training, clean-up drives and other activities. A respondent confided, 'they have to demonstrate commitment to our activities and events. Why should we bother with those who are not interested to attend anyway?' (Female, British4Environment, June 23, 2018). Residents from Botlog and Punting complained about this preference for 'active' residents. They have often been excluded from adaptation projects because they have to concentrate on securing food or earning a livelihood. An interviewee confided, 'given the chance I would have loved to join all those meetings. But I must tend to my family first and make sure that I can feed them' (Male, Botlog, June 14, 2018).

These findings reinforce the relationship between structural and recognitional justice. Social rules and cultural norms like hiya and utang na loob are deeply implicated in the production of recognitional injustice as they help determine who gets recognised in adaptation interventions of the NGOs. Only members of POs and active participants in NGO projects are deemed worthy of involvement in adaptation programmes to the detriment of the most vulnerable in the community.

\section{Discussion and conclusion}

Adaptation policies and projects should avoid strategies that exacerbate pre-existing equalities and climate vulnerability; however, research demonstrates adaptation interventions have the potential to displace, marginalise and reinforce existing inequalities within communities (Nagoda and Nightingale 2017; Wilmsen and Webber 2015). 'Climate justice' is a useful framework for helping policymakers and project proponents avoid maladaptive outcomes. 'Climate justice' has also been posited as a potential explanation for maladaptation, with various researchers arguing early deployments were too narrowly focused on 
instrumental definitions of distributive and procedural justice (Adger et al. 2016; Walker 2012). We, like others, endorse an expanded conceptualisation of climate - and adaptative - justice (Bulkeley et al. 2013; Schlosberg 2007) that gives greater attention to issues of recognitional and structural justice (Martin et al. 2013; McDermott et al. 2013; Schlosberg 2012). To this end, we presented an adapted framework, that expands the work of Pascual et al. (2014) to make explicit the dependent and reinforcing dimensions of justice - distributive justice depends upon procedural justice, which in turn requires a deep understanding of - and commitment to addressing - pre-existing structural and recognitional injustices.

We used this adapted framework to analyse a suite of adaptation interventions implemented by three international NGOs on the small island of Tambaliza in the Philippines. Our analysis shows that the poorest communities, which were also the most susceptible to extreme weather events, received fewer interventions than the more prosperous communities. Furthermore, the poorer sitios mainly received reactive interventions, like training programmes and early warning systems, while the more prosperous sitios also received proactive interventions designed to raise living standards and build climate resilience. This also reflects the fact that the more affluent and politically powerful sitios were able to voice their preferences for pro-active interventions to the implementing NGOs. In short, while the projects succeeded in raising the living standards and climate resiliency of the communities that received them, the overall programme reproduced and exacerbated pre-existing inequalities within and between the target communities whilst doing little to build the resilience of those most exposed to climate change risks. These results resonate with Eriksen et al.'s (2021) findings that adaptation efforts may increase pre-existing vulnerability and yield maladaptive outcomes.

Our analytical framework helped us identify both the strengths of the adaptation programmes as well as the proximate causes of the unjust outcomes. Our analysis shows that a lack of attention to structural and recognitional injustices skews participation in adaptation programmes and the distribution of impacts. The NGOs reportedly accounted for pre-existing baseline conditions; however, they did not question why the inequities endure or confronted the structures that brought about these pre-existing injustices. To do this they need to look beyond initial social conditions and ask how the present conditions are structural, how those structures have evolved, and where interventions to change them may be most effective' ((Young 2011), p. 181). We emphasise the need to look at how social structures, the routine ways that certain actions and practices are organised and maintained through various norms and expectations, imply disadvantages for some groups compared to others.

Our findings suggest that the structural injustices present in Tambaliza relate to complex socio-economic processes across multiple spatial scales. Some causes occur at the macro level, such as the inequitable allocation and investments in infrastructure and resources. Others occur at the micro level, such as persistent 'patron-client' relationships, which may provide short-term finance to poor households, but leave them indebted to their patrons. In addition, a review of Filipino social norms helps us understand the context in which adaptation interventions are experienced by local residents. Cultural norms such as saving face or reciprocal obligations underpin Filipino social relations and have implications for recognition. These deeply ingrained social arrangements and expectations help explain why NGOs choose members of established POs and reward residents who have engaged in past projects.

In terms of our analytical framework, the root cause of procedural and distributive injustice lies at the confluence of structural and recognitional injustice. It emphasises the need for deep engagement with the broader long-term structural inequities and that structural reforms must be central, rather than ancillary, to any attempt to build people's 
adaptive capacities to climate change. Structural change in government policies (such as a re-calibration of funding and increased investments in remote areas of the Philippines) and in NGO operations (such as independent engagements between the agencies and local officials to ensure transparency and minimise biases) are needed to redress the complex structural and recognitional injustices that persist within communities. This sits in stark contrast to current climate adaptation interventions in the Philippines that tend to be welfare-driven, ad hoc, and on a per-project basis (De Leon and Pittock 2017).

Our case study and analytical framework illuminate and reinforce issues raised in the recent literature on climate and adaptative justice. It reiterates that climate and adaptative justice is a multidimensional process (Bulkeley et al. 2013; Schlosberg 2012; Walker 2012). Our framework, however, emphasises the nested nature of these various dimensions of justice - distributive justice depends on procedural justice, which in turn depends on a deep understanding of pre-existing structural and recognitional injustices. It also embodies - and our case study exemplifies - Franks and Schreckenberg's (2015) observation that a just distribution of costs and benefits involves a 'recognition of power dynamics and strong procedures to avoid the elite capture of the benefits'. Finally, our framework emphasises that taking account of pre-existing systemic and recognitional injustices is a necessary condition for achieving distributive justice.

In conclusion, this paper presents a systematic framework for the analysis of adaptative justice which enable us to identify and evaluate multiple dimensions of justice. The approach used enabled us to uncover some of the deeply rooted causes of inequities that are beyond the scope of a distributive and procedural lens alone. In addition, the participatory workshops provided valuable insights into the justice-related problems facing the community of Tambaliza that were not captured in the household surveys. What, then, are some possible remedies to these forms of injustice? For adaptation to be just, future research and adaptation efforts should not overlook any of the dimensions of justice identified above. Those tasked with planning and implementing climate adaptation interventions must also continue to broaden their conceptions of adaptative justice. Multi-dimensional frameworks, such as the one presented in this paper, help attune policymakers and project proponents to the risks generated by pre-existing socio-economic and political conditions and help them design countervailing measures before community engagement begins. At a deeper level, this requires climate change adaptation to be understood as more than a technical activity that passes through well-defined stages (planning, community engagement, implementation, monitoring and evaluation), but as a deeply political process that can be easily subverted by the interests of the powerful, resulting not only in the sub-optimal allocation of scarce adaptative resources but also exacerbation of pre-existing inequalities and injustices. Here, the notion of participatory parity is particularly useful for thinking about how to mitigate the effects of politics on adaptation interventions. Although it may seem intuitive, adaptation programmes should be distributed in terms of needs rather than merit, networks or politics. Rather than quick wins, the success of an adaptation intervention should be judged by the lived experience and outcomes of the most exposed and least able to respond to the impacts of climate change. To realise justice in climate change adaptation, the voices of all people impacted by climate change - not just the powerful - should be recognised and valued. Finally, adaptation projects should provide everyone the opportunity to shape adaptation decisions and self-determine their climate futures.

Supplementary Information The online version contains supplementary material available at https://doi. org/10.1007/s10584-021-03266-y. 
Acknowledgements The authors would like to thank the residents of Tambaliza for their participation in this study. Special thanks to the NGOs who accommodated us during fieldwork and to the barangay officials who shared their time and knowledge with us. We would also like to thank Dr. Andrew van Hulten for helpful comments on an earlier draft of this article, as well as the three anonymous reviewers for their detailed and constructive feedback.

Funding Open Access funding enabled and organized by CAUL and its Member Institutions. This work was supported by the Internal Research Grant Scheme (IRGS) funding [grant number 2018-1-HDR-0015] of the School of Humanities and Social Sciences (HUSS), La Trobe University.

Data availability To protect the confidentiality and anonymity of our respondents, neither the data nor the source of data can be made publicly available.

\section{Declarations}

Ethics approval The research project has been granted ethics approval by the University Human Ethics Committee of La Trobe University on 21/03/2018 with application number HEC18038.

Open Access This article is licensed under a Creative Commons Attribution 4.0 International License, which permits use, sharing, adaptation, distribution and reproduction in any medium or format, as long as you give appropriate credit to the original author(s) and the source, provide a link to the Creative Commons licence, and indicate if changes were made. The images or other third party material in this article are included in the article's Creative Commons licence, unless indicated otherwise in a credit line to the material. If material is not included in the article's Creative Commons licence and your intended use is not permitted by statutory regulation or exceeds the permitted use, you will need to obtain permission directly from the copyright holder. To view a copy of this licence, visit http://creativecommons.org/licenses/by/4.0/.

\section{References}

Abian E (2016) Participatory capacity and vulnerability analysis of Tambaliza. Unpublished, Conservation International Tambaliza, Concepcion, Iloilo

Adams WM, Aveling R, Brockington D, Dickson B, Elliott J, Hutton J et al (2004) Biodiversity conservation and the eradication of poverty. Science 306(5699):1146-1149. https://doi.org/10.1126/science. 1097920

Adger WN, Paavola J, Huq S (2006) Toward justice in adaptation to climate change. In: Adger WN, Paavola J, Huq S, Mace MJ (eds) Fairness in adaptation to climate change. MIT Press, Cambridge, pp 1-19

Adger WN, Quinn T, Lorenzoni I, Murphy C (2016) Sharing the pain: perceptions of fairness affect private and public response to hazards. Ann Am Assoc Geogr 106(5):1079-1096. https://doi.org/10.1080/ 24694452.2016.1182005

Adler M (2012) Well-being and fair distribution: beyond cost-benefit analysis. Oxford University Press, Oxford

Agresti A (2007) An introduction to categorical data analysis. Wiley, Hoboken, NJ

Barnett J, O’Neill S (2010) Maladaptation. Glob Environ Chang 20(2):211-213. https://doi.org/10.1016/j. gloenvcha.2009.11.004

Barrett S (2013) Local level climate justice? Adaptation finance and vulnerability reduction. Glob Environ Chang 23(6):1819-1829. https://doi.org/10.1016/j.gloenvcha.2013.07.015

Beck V (2020) Two forms of responsibility: reassessing Young on structural injustice. Critical review of international social and political philosophy, 1-24. https://doi.org/10.1080/13698230.2020.1786307

Bgy Tambaliza (2012) Safe village guide for a disaster resilient community. Retrieved from Tambaliza, Concepcion, Iloilo

Brandstedt E, Brülde B (2019) Towards a theory of pure procedural climate justice. J Appl Philos 36(5):785-799. https://doi.org/10.1111/japp.12357

British4Environment (2017) Linking community resilience and sustainable coastal protection in Iloilo, Philippines

Bulkeley H, Carmin J, Castán Broto V, Edwards GAS, Fuller S (2013) Climate justice and global cities: mapping the emerging discourses. Glob Environ Chang 23(5):914-925. https://doi.org/10.1016/j.gloen vcha.2013.05.010 
Bulkeley H, Edwards GA, Fuller S (2014) Contesting climate justice in the city: examining politics and practice in urban climate change experiments. Glob Environ Chang 25:31-40. https://doi.org/10. 1016/j.gloenvcha.2014.01.009

Dawson N, Martin A, Danielsen F (2018) Assessing equity in protected area governance: approaches to promote just and effective conservation. Conserv Lett 11(2):e12388

De Leon EG, Pittock J (2017) Integrating climate change adaptation and climate-related disaster risk-reduction policy in developing countries: a case study in the Philippines. Clim Dev 9(5):471-478. https:// doi.org/10.1080/17565529.2016.1174659

Edwards GA, Reid L, Hunter C (2016) Environmental justice, capabilities, and the theorization of wellbeing. Prog Hum Geogr 40(6):754-769

Enriquez VG (1993) Developing a Filipino psychology. In: Kim U, Berry JW (eds) Indigenous psychologies: research and experience in cultural context. Sage, London, pp 152-192

Eriksen S, Aldunce P, Bahinipati CS, Martins RDA, Molefe JI, Nhemachena C et al (2011) When not every response to climate change is a good one: identifying principles for sustainable adaptation. Clim Dev 3(1):7-20. https://doi.org/10.3763/cdev.2010.0060

Eriksen S, Schipper ELF, Scoville-Simonds M, Vincent K, Adam HN, Brooks N et al (2021) Adaptation interventions and their effect on vulnerability in developing countries: help, hindrance or irrelevance? World Dev 141:105383. https://doi.org/10.1016/j.worlddev.2020.105383

First Response Ireland. (2016). Evaluation of first response Ireland's typhoon Haiyan/ Yolanda emergency response and recovery Programme. Ireland

Franks P, Schreckenberg K (2015). Advancing equity in protected area conservation (IIED briefing). In: London: IIED

Fraser N (2009) Social justice in the age of identity politics. Geographic thought: a praxis perspective. Routledge, London, pp 72-91

Fraser N (2010) Scales of justice: reimagining political space in a globalizing world. Columbia University Press, New York

Graham S, Barnett J, Fincher R, Mortreux C, Hurlimann A (2015) Towards fair local outcomes in adaptation to sea-level rise. Clim Chang 130(3):411-424. https://doi.org/10.1007/s10584-014-1171-7

Graham S, Barnett J, Mortreux C, Hurlimann A, Fincher R (2018) Local values and fairness in climate change adaptation: insights from marginal rural Australian communities. World Dev 108:332-343. https://doi.org/10.1016/j.worlddev.2017.12.008

Hanley T, Binas R, Murray J, Tribunalo B (2016). IASC inter-agency humanitarian evaluation of the typhoon Haiyan response. Retrieved from New York: https://interagencystandingcommittee.org/ system/files/evaluation_report_iahe_haiyan_december_2016.pdf

Hill H (2008) Globalization, inequality, and local-level dynamics: Indonesia and the Philippines. Asian economic policy review 3(1):42-61. https://doi.org/10.1111/j.1748-3131.2008.00087.x

Holland B (2017) Procedural justice in local climate adaptation: political capabilities and transformational change. Environmental Politics 26(3):391-412. https://doi.org/10.1080/09644016.2017. 1287625

Honneth A (1995) The struggle for recognition: the moral grammar of social conflicts. Polity Press, Cambridge, UK

IPCC (2014) Climate change 2014: synthesis report. Contribution of working groups I, II and III to the Fifth Assessment Report of the Intergovernmental Panel on Climate Change, Geneva, Switzerland. Retrieved from https://archive.ipcc.ch/pdf/assessment-report/ar5/syr/SYR_AR5_FINAL_full_ wcover.pdf

Krumpal I (2013) Determinants of social desirability bias in sensitive surveys: a literature review. Qual Quant 47(4):2025-2047. https://doi.org/10.1007/s11135-011-9640-9

Lum T, Margesson R (2014) Typhoon Haiyan (Yolanda): US and international response to Philippines disaster. Current Politics and Economics of South, Southeastern, and Central Asia 23(2):209. Retrieved from https://fas.org/sgp/crs/row/R43309.pdf

Mah A, Wang X (2019) Accumulated injuries of environmental injustice: living and working with petrochemical pollution in Nanjing, China. Ann Am Assoc Geogr 109(6):1961-1977. https://doi.org/10. $1080 / 24694452.2019 .1574551$

Martin A, McGuire S, Sullivan S (2013) Global environmental justice and biodiversity conservation. Geogr J 179(2):122-131. https://doi.org/10.1111/geoj.12018

Martin A, Gross-Camp N, Kebede B, McGuire S, Munyarukaza J (2014) Whose environmental justice? Exploring local and global perspectives in a payments for ecosystem services scheme in Rwanda. Geoforum 54:167-177. https://doi.org/10.1016/j.geoforum.2013.02.006

Martin A, Akol A, Gross-Camp N (2015) Towards an explicit justice framing of the social impacts of conservation. Conserv Soc 13(2):166-178. https://doi.org/10.4103/0972-4923.164200 
McDermott M, Mahanty S, Schreckenberg K (2013) Examining equity: a multidimensional framework for assessing equity in payments for ecosystem services. Environ Sci Pol 33:416-427. https://doi. org/10.1016/j.envsci.2012.10.006

Mercado L (1976) Elements of Filipino philosophy. Divine Word, Tacloban

Mikulewicz M (2018) Politicizing vulnerability and adaptation: on the need to democratize local responses to climate impacts in developing countries. Clim Dev 10(1):18-34. https://doi.org/10. $1080 / 17565529.2017 .1304887$

Mill JS (1998) Utilitarianism. Oxford University Press, Oxford

Municipality of Concepcion (2017) 2017-2021 Municipal Disaster Risk Reduction and Management Plan. https://mariaaurora.gov.ph/municipal-disaster-risk-reduction-management-mdrrmo/

Nagoda S, Nightingale AJ (2017) Participation and power in climate change adaptation policies: vulnerability in food security programs in Nepal. World Dev 100:85-93. https://doi.org/10.1016/j.world dev.2017.07.022

National Statistical Coordinating Board (2009) 2003 City and municipality level estimates of poverty. Retrieved from Manila, Philippines: https://psa.gov.ph/sites/default/files/2003\%20SAE\%20of\% 20poverty\%20\%28Full\%20Report\%29_0.pdf

O'Brien K, Leichenko RM (2003) Winners and losers in the context of global change. Ann Assoc Am Geogr 93(1):89-103. https://doi.org/10.1111/1467-8306.93107

Paavola J (2008) Livelihoods, vulnerability and adaptation to climate change in Morogoro, Tanzania. Environ Sci Pol 11(7):642-654

Paavola J, Adger WN (2006) Fair adaptation to climate change. Ecol Econ 56(4):594-609. https://doi. org/10.1016/j.ecolecon.2005.03.015

Paavola J, Adger N, Huq S (2006) Multifaceted justice in adaptation to climate change. In: Adger WN, Paavola J, Huq S, Mace MJ (eds) Fairness in adaptation to climate change. MIT Press, Cambridge, pp 263-277

Pascual U, Phelps J, Garmendia E, Brown K, Corbera E, Martin A et al (2014) Social equity matters in payments for ecosystem services. Bioscience 64(11):1027-1036. https://doi.org/10.1093/biosci/biu146

Peacock WG, Morrow BH, Gladwin H (1997) Hurricane Andrew: ethnicity, gender, and the sociology of disasters. Routledge, New York

Penaflor R (2013) Save Sitio Botlog Gamay: a rebuilding of homes project. Retrieved from https://lifex tenders.wixsite.com/lifextenders/save-sitio-botlog-gamay-project

Philippine Statistics Authority (2017) 2015 Census of Population, Report No. 2: demographic and socioeconomic characteristics Philippines. Retrieved from https://psa.gov.ph/sites/default/files/2015\% 20CPH_REPORT\%20NO.\%202_PHILIPPINES.pdf

Popke J, Curtis S, Gamble DW (2016) A social justice framing of climate change discourse and policy: adaptation, resilience and vulnerability in a Jamaican agricultural landscape. Geoforum 73:70-80. https://doi.org/10.1016/j.geoforum.2014.11.003

Republic of the Philippines (1987) The Constitution of the Republic of the Philippines. Retrieved from https://www.officialgazette.gov.ph/constitutions/1987-constitution/

Roche C (2000) Impact assessment: seeing the wood and the trees. Dev Pract 10(3-4):543-555. https:// doi.org/10.1080/09614520050116703

Rogers S (2014) Betting on the strong: local government resource allocation in China's poverty counties. J Rural Stud 36(C):197-206. https://doi.org/10.1016/j.jrurstud.2014.08.001

Sacred Aid UK (2016) Evaluation of Sacred Aid UK's typhoon Haiyan rehabilitation and resilience building programme. Waterloo, London

Schlosberg D (2004) Reconceiving environmental justice: global movements and political theories. Environmental Politics 13(3):517-540. https://doi.org/10.1080/0964401042000229025

Schlosberg D (2007) Defining environmental justice: theories, movements, and nature. Oxford University Press, New York

Schlosberg D (2012) Climate justice and capabilities: a framework for adaptation policy. Ethics Int Aff 26(4):445-461. https://doi.org/10.1017/S0892679412000615

Schlosberg D, Collins LB (2014) From environmental to climate justice: climate change and the discourse of environmental justice. Wiley Interdiscip Rev Clim Chang 5(3):359-374. https://doi.org/ $10.1002 /$ wcc. 275

Scott JC, Kerkvliet BJ (1977) How traditional rural patrons lose legitimacy: a theory with special reference to Southeast Asia. In: Schmidt SW (ed) Friends followers and factions: a reader in political Clientielism. University of California Press, Berkeley

See J, Wilmsen B (2020) Just adaptation? Generating new vulnerabilities and shaping adaptive capacities through the politics of climate-related resettlement in a Philippine coastal city. Glob Environ Chang 65:102188. https://doi.org/10.1016/j.gloenvcha.2020.102188 
Sharpe D (2015) Your Chi-Square test is statistically significant: now what? Pract Assess Res Eval 20(8):1-10

Shue H (1999). Global environment and international inequality. Int Aff 75(3):531-545. Retrieved from https://www.jstor.org/stable/2623635

Sikor T, Martin A, Fisher J, He J (2014) Toward an empirical analysis of justice in ecosystem governance. Conserv Lett 7(6):524-532. https://doi.org/10.1111/conl.12142

Smit B, Burton I, Klein RJ, Wandel J (2000) An anatomy of adaptation to climate change and variability. Clim Chang 45:223-251. https://doi.org/10.1023/A:1005661622966

Tapsell SM, Penning-Rowsell EC, Tunstall SM, Wilson TL (2002) Vulnerability to flooding: health and social dimensions. Philosophical transactions of the royal society of London. Series A: Math Physic Engine Sci 360(1796):1511-1525. https://doi.org/10.1098/rsta.2002.1013

Thomas D, Twyman C (2005) Equity and justice in climate change adaptation amongst natural-resourcedependent societies. Glob Environ Chang 15(2):115-124. https://doi.org/10.1016/j.gloenvcha.2004.10. 001

Togias A, Fenton MJ, Gergen PJ, Rotrosen D, Fauci AS (2010) Asthma in the inner city: the perspective of the National Institute of Allergy and Infectious Diseases. J Allergy Clin Immunol 125(3):540-544

Vähämäki J (2015) The results agenda in Swedish development cooperation: cycles of failure or reform success. In: The politics of evidence and results in international development. Practical Action, Rugby, pp $135-154$

Walker G (2012) Environmental justice: concepts, evidence and politics. Routledge, London

Weiss EB (1989) In fairness to future generations international law, common patrimony, and intergenerational equity. United Nations University, Tokyo

Wilmsen B, Rogers S (2019) Planned resettlement to avoid climatic hazards: what prospects for just outcomes in China? Asia Pac Viewp 60(2):118-131. https://doi.org/10.1111/apv.12232

Wilmsen B, Webber M (2015) What can we learn from the practice of development-forced displacement and resettlement for organised resettlements in response to climate change? Geoforum 58:76-85. https://doi.org/10.1016/j.geoforum.2014.10.016

World Bank (2019) The World Bank Group action plan on climate change adaptation and resilience. Retrieved from http://documents1.worldbank.org/curated/en/519821547481031999/The-World-BankGroups-Action-Plan-on-Climate-Change-Adaptation-and-Resilience-Managing-Risks-for-a-MoreResilient-Future.pdf

Young IM (1990) Justice and the politics of difference. Princeton University Press, Princeton

Young IM (2011) Responsibility for justice. Oxford University Press, Oxford

Publisher's note Springer Nature remains neutral with regard to jurisdictional claims in published maps and institutional affiliations. 